\title{
molecules
}

ISSN 1420-3049

http://www.mdpi.org

\section{Fluorescent 2,7-Dialkylamino-[1,8]-Naphthyridines: Preparation and Spectroscopic Properties}

\author{
Christoph Hoock $^{1 *}$, Jörg Reichert ${ }^{2}$ and M. Schmidtke ${ }^{2}$ \\ ${ }^{1}$ BYK-Gulden-Lomberg GmbH, D-78467 Konstanz, Germany \\ E-mail: christoph.hoock@byk.de \\ ${ }^{2}$ Institute for Virology, University of Jena, Winzerlaerstr. 10, D-07745 Jena, Germany \\ *Author to whom correspondence should be addressed.
}

Received: 4 June 1999 / Accepted: 10 August 1999 / Published: 6 September 1999

\begin{abstract}
Substitution of 4-methyl-[1,8]-naphthyridine in 2 and 7 position by alkylamines leads to highly fluorescent compounds. The arrangement of hydrogen donor and acceptor groups of these naphthyridines allows interactions with guanine and guanine cytosine base pairs. The described synthesis offers easy access to these small and stable fluorescent probes.
\end{abstract}

Keywords: Naphthyridines, Fluorescence, Fluorescent probes.

\section{Introduction}

Fluorescent compounds are widely used as markers in biochemical and nucleic acid technologies and are the subject of intensive investigations. Many of the available markers, such as xanthene dyes, fulfil the necessary requirement for markers by having very high molar extinction and quantum yield. On the other hand, it is recognised that these compounds, due to the relatively large size, could interfere or even disturb the geometric structures under investigation. This may limit their use due to artefacts [1].

(C) 1999 by the authors. Reproduction of this article, by any means, is permitted for noncommercial purposes. 
Coumarins [2], azacoumarins [3] and chinolones [4] are well known fluorescent dyes with a molecular shape and size similar to naphthyridines but differing in their capabilities to form hydrogen bonds. The dialkylamino substituted 4-methyl-[1.8] naphthyridines described here are new and stable compounds that can be obtained easily through a synthesis consisting of only a few steps, and show an interesting fluorescence behaviour. Their steric characteristics and ability to form hydrogen bonds are similar to donor substituted pyridopyrimidines [5] or purine bases such as guanine. The fluorescence of naphthyridines in the VIS region and thus their potential application as fluorescent markers, especially in molecular biology and related fields, has not been described previously. So they should be especially useful for fluorescent markers of nucleic acids [6].

\section{Results and Discussion}

\section{Syntheses of 2.7-dialkylamino-4-methyl-[1.8]-naphthyridines}

The synthesis of 2,7-di-( $N$-alkylamino)-substituted 4-methyl-[1,8]-naphthyridines (Scheme 1) can be accomplished by nucleophilic substitution of the 2,7-dichlor- or 7-acetamido-2-chlor-derivative of 4-methyl-[1,8]-naphthyridine with alkylamines. The synthesis of the starting materials $\mathbf{1}$ and $\mathbf{2}$ was carried out according to the method of Seide [7] and Petrow [8]. 2,7-Dichlor-4-methyl-[1,8]naphthyridine 1 reacted with five different amines (Scheme 1). These highly fluorescent 4-methyl-2.7dialkyamino-1.8-naphthyridines have not been described by others [9,10].

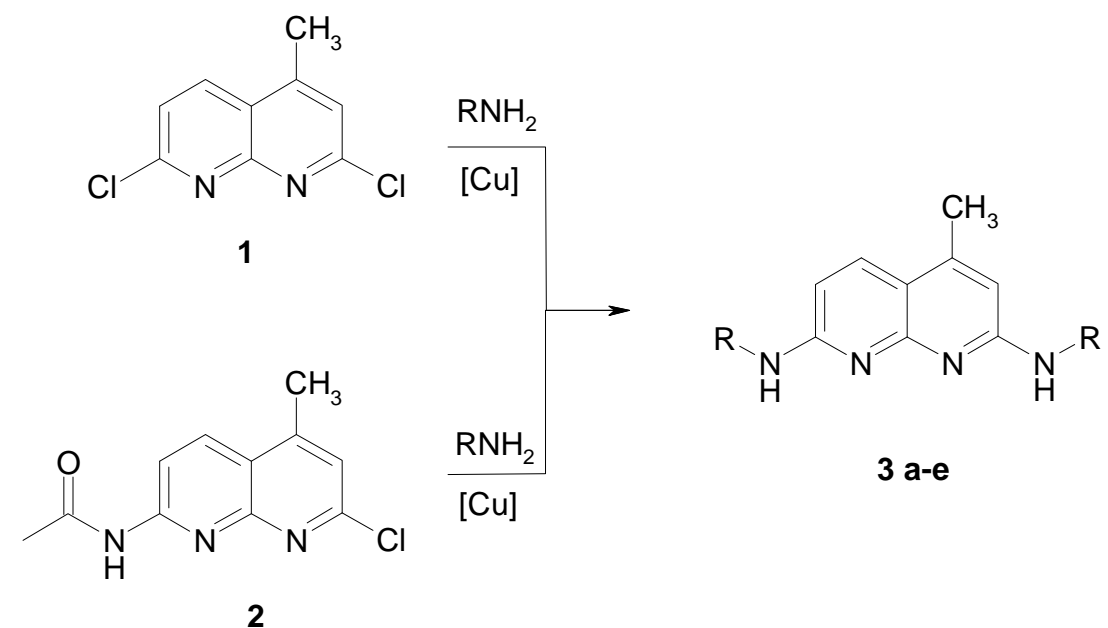

Scheme 1. Syntheses of 2,7-Di-( $N$-alkylamino)-4-methyl-[1,8]-naphthyridines.

All reactions were carried out at elevated temperatures and pressure in the presence of equimolar quantities of copper powder. Except for methylamine which was prepared as a $30 \%(\mathrm{w} / \mathrm{v})$ solution in methanol, all reactions were performed without additional solvent. Even at high temperature, liquid 
ammonia did not react with 2,7-dichlor-4-methyl-[1,8]-naphthyridin $\mathbf{1}$ to form a 2,7-diamino compound. In contrast to substitutions of the chlorine atoms at position 2 and 7 with sodium alkoxides [11], the complete substitution with amines needed vigorous conditions. In order to avoid monosubstitution, it was necessary to heat the reaction mixture for 12 to $18 \mathrm{~h}$ and to add copper powder in equimolar amounts. In our synthesis method, the method of Carboni and coworkers [12] was modified to yield cleaner products and to achieve shorter reaction times. Further shortening of the reaction times led to mixtures of the substitution products without preference for 2 or 7-substitution. Because of the donor effect of the nitrogen, the first substitution through an amine leads to decreased reactivity of the heterocyclus.

Using the above mentioned reaction we tried to obtain $2-N$-alkylamino-7-amino-4-methyl-[1,8]naphthyridines by reacting 7-acetamido-2-chlor-4-methyl-[1,8]-naphthyridin 2 with alkylamines. The products of these reactions however are identical to those of the reaction with 1 . The yields and $R_{f}$ values of the products are listed in table 1.

Table 1. Yield, $R_{\mathrm{f}}$-Values and Quantum Yield of Fluorescence $\Phi$.

\begin{tabular}{cccccc}
\hline Nr. & $\mathrm{R}$ & $\mathbf{1}^{{\text {Yield }[\%]^{\mathrm{a}}}}$ & $\mathbf{2}$ & $\boldsymbol{R}_{f}$ & $\Phi$ \\
\hline 3a & $\mathrm{CH}_{3}$ & n. a. & 34 & 0.20 & 0.25 \\
3b & $n-\mathrm{C}_{3} \mathrm{H}_{7}$ & 49 & 18 & 0.46 & 0.19 \\
3c & $n-\mathrm{C}_{4} \mathrm{H}_{9}$ & 65 & 22 & 0.55 & 0.28 \\
3d & $n-\mathrm{C}_{2} \mathrm{H}_{4}-\mathrm{O}-\mathrm{CH}_{3}$ & 20 & 22 & 0.26 & 0.24 \\
3e & $n-\mathrm{C}_{6} \mathrm{H}_{13}$ & 65 & 2 & 0.78 & 0.26 \\
\hline
\end{tabular}

${ }^{\mathrm{a}}$ Yields starting with $\mathbf{1}$ or $\mathbf{2} ;{ }^{\mathrm{b}}$ not reacted with $\mathbf{1}$.

The double substitution of 2,7-dichlor-4-methyl-[1,8]-naphthyridin 1 and of 7-acetamido-2-chlor-4methyl-[1,8]-naphthyridin 2 by alkylamines was proved by mass spectrometry, ${ }^{1} \mathrm{H}-\mathrm{NMR}$-spectra and elemental analysis. Thus it could be shown, that under the reaction conditions described here, the chlorine as well as acetamide were substituted completely, monosubstitution was not observed.

\section{Fluorescence and UV Behaviour}

The dialkylamino-4-methyl-naphthyridines 3a-e are yellow to light green solids. A 1 x $10^{-3} \mathrm{M}$ solution of these naphthyridines in methanol shows UV absorptions between 320 and $400 \mathrm{~nm}$ with excitation of $n \rightarrow \pi^{*}$ transitions. This was proved by adding HMPT to the solutions of the naphthyridines in methanol. The enhanced polarity led to a blue shift of the $n \rightarrow \pi^{*}$ transitions and a red shift of the $\pi \rightarrow \pi^{*}$ transitions. 
Diluted solutions show blue fluorescence even in daylight. Using an excitation wavelength of 340 $\mathrm{nm}$ a band without specific structure could be observed in the area between $360-500 \mathrm{~nm}$. The fluorescence maxima are blue-shifted compared to 8-azacoumarins and 8-azaquinolones [13]. The fluorescence maximum of $\mathbf{3 b}$ in aqueous solutions $(0.1 \mathrm{mM})$ can be shifted from $435 \mathrm{~nm}$ to $425 \mathrm{~nm}$ by adding DNA (1mg/l herring sperm [14]). The nature of the interaction between DNA and naphthyridines has not yet been determined.

The quantum yield of fluorescence $\Phi$ was determined using acridine orange as a standard [15] (Table 1). The quantum yields were not as high as those observed for classical fluorescence markers such as fluorescein, but the smaller size of the compounds described here and their ability to form hydrogen bonds can sometimes be more important than high quantum yields.

\section{Biological use}

Using fluorescence microscopy [16] we could show that 3a enters selectively the nucleus of MDCK-cells colouring the nucleoli (Fig. 1).

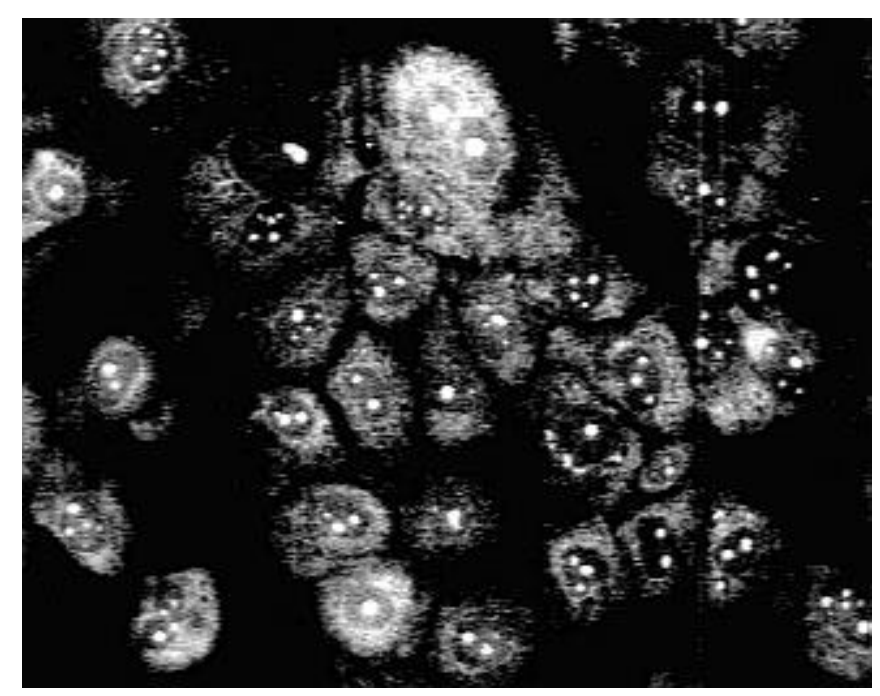

Figure 1. Fluorescence pattern in MDCK-cells after staining with 3a.

Staining with these naphthyridine leads to an intensive blue fluorescence of nuclei and nucleosomes when using UV or blue excitation light. Diffuse fluorescence signals were detected in the cytoplasm of 3a treated Madin Darby canine kidney (MDCK) cells. All other synthesised alkylamino substituted naphthyridines (3b-3e) enter the cell but remain in the cytoplasm and are concentrated in the nuclear membrane (Fig. 2). The fading of the fluorescence of $\mathbf{3 b - 3 e}$ at ambient temperature (quenching) seems to be caused by enzymatic processes in the cytoplasm. 


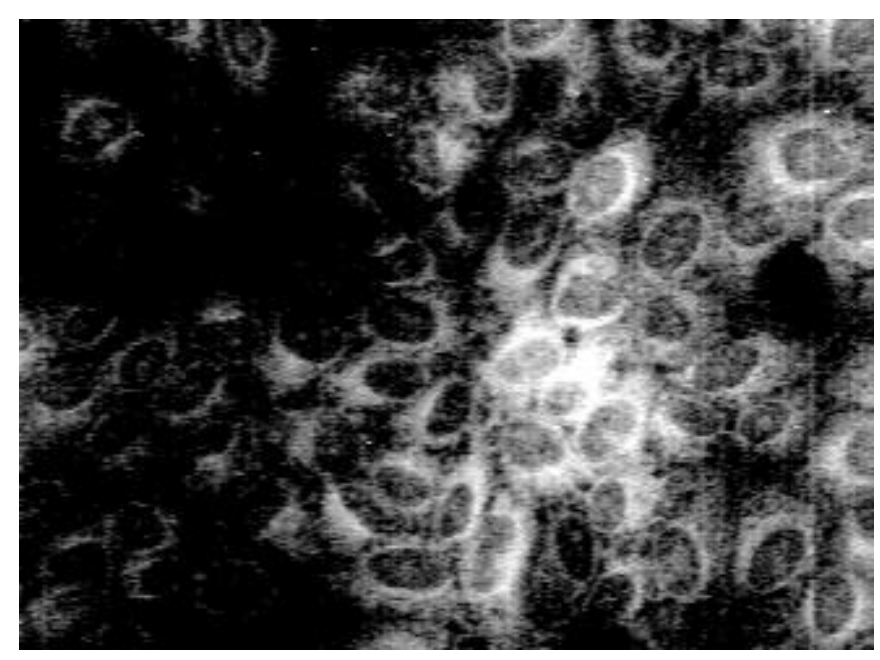

Figure 2. Fluorescence pattern in MDCK-cells after staining with 3b.

Alkylamines and arylamines of [1,8]-naphthyridines show interesting biological properties [12]. The biological properties of these 4-methyl-2.7-dialkylamino-[1.8]-naphthyridines will be published elsewhere [17].

Even when these heterocycles are not stable in the cytoplasm for prolonged periods it is possible to use them as fluorescent probes of the cytoplasm and for staining experiments. Due to their easy access, high fluorescence quantum yield, and stability against irradiation and oxidation the 2,7-diaminosubstituted 4-methyl-[1,8]-naphthyridines are useful as fluorescent dyes for staining and marking experiments.

\section{Experimental}

\section{General}

Melting points were measured on a PHMK 80/2920 VEB Rapido and are uncorrected. UV/VIS spectra were measured on a Perkin Elmer spectrometer model LAMBDA 15 UV/VIS spectrometer. Fluorescence spectra and quantum yields were measured on a SLM AMINCO- model MHF 48000 spectrofluorometer (Urbana, Illinois, USA). NMR spectra were taken on a BRUKER AVANCE DRX 300 and DRX 500 spectrometer using TMS as a standard. J-values are given in Hz, shifts are given in ppm. Microanalyses were performed on a FOSS-HERAEUS CHNO rapid. Analytical thin layer chromatography was carried out using precoated Merck Kieselgel 60 and was visualised under UV at $346 \mathrm{~nm}$. The solvent for TLC was a mixture of chloroform: methanol: HAc 10:1:0,5. $\mathrm{R}_{\mathrm{f}}$ values and yields of 2,7-dialkyl-4-methyl-[1,8]naphthyridines are shown in table 1. All alkylamines were distilled prior to use.

The fluorescence investigations under in vitro conditions were performed in MDCK cells (provided by the Institute of Influenza viruses, Petersburg, Russia) as described previously [18]. The cells were 
propagated in Eagle's minimal essential medium supplemented with $100 \mathrm{U} / \mathrm{ml}$ penicilline, $100 \mu \mathrm{g} / \mathrm{ml}$ streptomycine (SIGMA, Deisenhofen, Germany), and 10\% fetal calf serum (PAA, Linz, Austria). Serial dilutions of naphthyridine derivatives were added to the supernatant of $48 \mathrm{~h}\left(37^{\circ}, 5 \% \mathrm{CO}_{2}\right)$ preincubated $90 \%$ confluent MDCK monolayers. After further $24 \mathrm{~h}$ of incubation with either 3a or 3b at $37^{\circ}$ with $5 \% \mathrm{CO}_{2}$, the cells were fixed with methanol. The fluorescence label within the cells was visualized by fluorescence microscopy (Wild Leitz GmbH, Wetzlar, Germany) using an excitation wavelength of $355-425 \mathrm{~nm}$.

General procedure for the generation of 2,7-dialkylaminosubstituted 4-methyl-[1,8]-naphthyridines 3a-e

$2 \mathrm{~g}$ of the chloro compound [7] 1 or 2 and $50 \mathrm{mg}$ copper powder and $50 \mathrm{ml}$ of n-alkylamine were heated under pressure at $160{ }^{\circ} \mathrm{C}$ for $12 \mathrm{~h}$ with magnetic stirring. Except in the case of methylamine ( $30 \% \mathrm{w} / \mathrm{v}$ solution in methanol), no additional solvent was used.

After cooling, the alkyamine was removed under vacuum. The residue was diluted with water, acidified with diluted hydrochloric acid and filtered to remove unreacted starting material. The $\mathrm{pH}$ of the filtrate was adjusted to 8 using diluted ammonia and the product was then extracted with chloroform. The organic layer was dried with $\mathrm{MgSO}_{4}$, strongly concentrated (ca. 1-2 ml) and then precipitated by the addition of cold diethyl ether. The product was washed twice with cold diethyl ether ( $2 \times 10 \mathrm{ml}$ ), dryed and finally purified by either recrystallisation from ethanol or by column chromatography over silica (chloroform-methanol (10:1)).

\section{2,7-Dimethylamino-4-methyl-[1.8]-naphthyridine 3a}

Yellow powder, mp $261^{\circ} \mathrm{C}$ (dec.) (Found: C, 65.8; H, 7.3; N, 26.0. Calc. for $\mathrm{C}_{11} \mathrm{H}_{14} \mathrm{~N}_{4}(202.26) \mathrm{C}$, 65.3; H, 7.0; N, 26.2); $\delta_{\mathrm{H}}\left(500 \mathrm{MHz}, \mathrm{CDCl}_{3}\right) 2.41$ (3 H, s, $\mathrm{CH}_{3}-\mathrm{Naphth}$ ), 3.04 (6 H, s, N-CH $), 6.15$ (1 H, s, H3), 6.30 (1 H, d, J 9.14, H6), $7.74\left(1 \mathrm{H}, \mathrm{d}, \mathrm{J} \text { 9.14, H5); } \delta_{\mathrm{C}}\left(75 \mathrm{MHz}, \mathrm{CDCl}_{3}\right) 18.5 \text { (Naphth-CH }\right)_{3}$, 28.8/28.9 ( $\left.\mathrm{CH}_{3}\right), 110.7$ (C3), 133.8 (C5), 134.9 (C6), 145.6 (C4), 157.1 (C9), 160.1/161.0 (C2/C7); MS $\left(\mathrm{ESI}^{+}\right): \mathrm{Da} / \mathrm{e}(\%) 203.1(100)(\mathrm{M}+\mathrm{H})^{+}$.

\section{2,7-Dipropylamino-4-methyl-[1.8]-naphthyridine 3b}

Light yellow powder, mp $242^{\circ} \mathrm{C}$ (dec.) (Found: $\mathrm{C}, 69.7 ; \mathrm{H}, 8.6 ; \mathrm{N}, 21.7$ Calc. for $\mathrm{C}_{15} \mathrm{H}_{22} \mathrm{~N}_{4}(258.37$ ) $\mathrm{C}, 69.7 ; \mathrm{H}, 8.8 ; \mathrm{N}, 21.5) ; \delta_{\mathrm{H}}\left(300 \mathrm{MHz}, \mathrm{CDCl}_{3}\right) 1.02\left(6 \mathrm{H}, \mathrm{t}, \mathrm{J} 7.31,2 \mathrm{x} \gamma-\mathrm{CH}_{3}\right), 1.76(4 \mathrm{H}, \mathrm{m}, \mathrm{J}$ 7.31, 2x $\left.\beta-\mathrm{CH}_{2}\right), 2.44$ (3 H, s, Naphth- $\left.\mathrm{CH}_{3}\right), 3.33\left(4 \mathrm{H}, \mathrm{br}, 2 \mathrm{x} \alpha-\mathrm{CH}_{2}\right), 6.18(1 \mathrm{H}, \mathrm{s}, \mathrm{H} 3), 6.34$ (1 H, d, J 7.77, H6), $7.71(1 \mathrm{H}, \mathrm{d}, \mathrm{J} 7.77, \mathrm{H} 5) ; \delta_{\mathrm{C}}\left(75 \mathrm{MHz}, \mathrm{CDCl}_{3}\right) 11.5\left(\gamma-\mathrm{CH}_{3}\right), 18.5\left(\mathrm{Naphth}-\mathrm{CH}_{3}\right), 22.4\left(\beta-\mathrm{CH}_{2}\right)$, $44.4\left(\alpha-\mathrm{CH}_{2}\right), 103.1$ (C3), 134.8 (C5), 136.8 (C6), 146.8 (C4), 162.3/162.7 (C2/C7); MS (EI $\left.{ }^{+}\right) \mathrm{m} / \mathrm{z}(\%)$ : 258 (76) $\left(\mathrm{C}_{15} \mathrm{H}_{22} \mathrm{~N}_{4}^{+}\right), 243(96)\left(\mathrm{C}_{14} \mathrm{H}_{19} \mathrm{~N}_{4}^{+}\right), 229$ (100) $\left(\mathrm{C}_{13} \mathrm{H}_{17} \mathrm{~N}_{4}^{+}\right), 216$ (89) $\left(\mathrm{C}_{12} \mathrm{H}_{16} \mathrm{~N}_{4}^{+}\right), 201$ (62) $\left(\mathrm{C}_{13} \mathrm{H}_{15} \mathrm{~N}_{3}^{+}\right),\left(\mathrm{C}_{11} \mathrm{H}_{13} \mathrm{~N}_{4}^{+}\right), 188(98)\left(\mathrm{C}_{10} \mathrm{H}_{12} \mathrm{~N}_{4}^{+}\right), 174(50)\left(\mathrm{C}_{9} \mathrm{H}_{10} \mathrm{~N}_{4}^{+}\right), 158(47)\left(\mathrm{C}_{9} \mathrm{H}_{8} \mathrm{~N}_{3}^{+}\right), \mathrm{MS}(\mathrm{ESI}) \mathrm{Da} / \mathrm{e}$ 
(\%): $259.5(100)(\mathrm{M}+\mathrm{H})^{+}$.

\section{2,7-Dibutylamino-4-methyl-[1.8]-naphthyridine 3c}

Yellow-green powder, mp $195^{\circ} \mathrm{C}$ (Found: C, 71.3; H, 9.2; N, 19.4 Calc. for $\mathrm{C}_{17} \mathrm{H}_{26} \mathrm{~N}_{4}(286.42) \mathrm{C}$, 71.3; H, $9.1 \mathrm{~N}, 19.6$; $\delta_{\mathrm{H}}\left(300 \mathrm{MHz}, \mathrm{DMSO}-\left(\mathrm{D}_{6}\right)\right) 0.91\left(6 \mathrm{H}, \mathrm{t}, \mathrm{J} 7.31, \delta-\mathrm{CH}_{3}\right), 1.37(4 \mathrm{H}, \mathrm{m}, \mathrm{J} 7.31, \gamma-$ $\left.\mathrm{CH}_{2}\right), 1.55$ (4 H, m, J 7.31, $\left.\beta-\mathrm{CH}_{2}\right), 2.44\left(3 \mathrm{H}, \mathrm{s}, \mathrm{Naphth}-\mathrm{CH}_{3}\right), 3.40\left(4 \mathrm{H}, \mathrm{br}, \alpha-\mathrm{CH}_{2}\right), 6.59(1 \mathrm{H}, \mathrm{s}, \mathrm{H} 3)$, $6.67(1 \mathrm{H}, \mathrm{d}, \mathrm{J} 9.14, \mathrm{H} 6), 7.95(1 \mathrm{H}, \mathrm{br}, \mathrm{H} 5) ; \delta_{\mathrm{C}}\left(75 \mathrm{MHz}, \mathrm{CDCl}_{3}\right) 13.8\left(\delta-\mathrm{CH}_{2}\right), 18.6\left(\mathrm{Naphth}-\mathrm{CH}_{3}\right)$, $20.3\left(\gamma-\mathrm{CH}_{2}\right), 31.1\left(\beta-\mathrm{CH}_{2}\right), 42.4\left(\alpha-\mathrm{CH}_{2}\right), 114.1(\mathrm{C} 3), 135.0$ (C5), 136.7 (C6), $148.6(\mathrm{C} 4), 160.0$ (C2/C7); MS (EI') m/z (\%): $286(70)\left(\mathrm{C}_{17} \mathrm{H}_{26} \mathrm{~N}_{4}^{+}\right), 257(100)\left(\mathrm{C}_{15} \mathrm{H}_{21} \mathrm{~N}_{4}^{+}\right), 243(79)\left(\mathrm{C}_{14} \mathrm{H}_{19} \mathrm{~N}_{4}^{+}\right), 230(74)$ $\left(\mathrm{C}_{13} \mathrm{H}_{19} \mathrm{~N}_{4}^{+}\right), 215$ (19) $\left(\mathrm{C}_{12} \mathrm{H}_{15} \mathrm{~N}_{4}^{+}\right), 201$ (45) $\left(\mathrm{C}_{11} \mathrm{H}_{13} \mathrm{~N}_{4}^{+}\right), 188$ (62) $\left.\mathrm{C}_{10} \mathrm{H}_{12} \mathrm{~N}_{4}^{+}\right), 174$ (30), 158 (30), MS $\left(\mathrm{ESI}^{+}\right) \mathrm{Da} / \mathrm{e}(\%): 287(100)(\mathrm{M}+\mathrm{H})^{+}, 573(11)(2 \mathrm{M}+\mathrm{H})^{+}$.

\section{$N^{2}, N^{7}$-Bis-(2-methoxy-ethyl)-4-methyl-[1,8]naphthyridine-2,7-diamine 3d}

Pale yellow powder, mp 104-106 ${ }^{\circ} \mathrm{C}$ (Found: C, 62.1; H, 7.7 ; N, 19.3; Calc. for $\mathrm{C}_{15} \mathrm{H}_{22} \mathrm{~N}_{4} \mathrm{O}_{2}(232.29)$ $\mathrm{C}, 62.1 ; \mathrm{H}, 7.7 ; \mathrm{N}, 19.1) ; \delta_{\mathrm{H}}\left(300 \mathrm{MHz}, \mathrm{CDCl}_{3}\right) 2.42\left(3 \mathrm{H}, \mathrm{s}, \mathrm{Naphth}-\mathrm{CH}_{3}\right), 3.38\left(6 \mathrm{H}, \mathrm{s}, 2 \mathrm{x} \mathrm{O}-\mathrm{CH}_{3}\right)$, 3.60 (4 H, t, J 5.25, 2x CH$-\mathrm{O}), 3.70$ (4 H, t, J 5.02, 2x N-CH $), 6.26$ (1 H, s, H3), 6.39 (1 H, d, J 8.91,

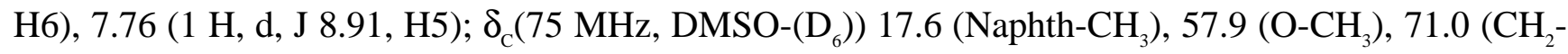
O), 109.4 (C3), 132.7 (C5), 132.8 (C6), 143.8 (C4), 157.1 (C9), 158.8/158.9 (C2/C7); MS (EI') m/z (\%): 290 (53) $\left(\mathrm{C}_{15} \mathrm{H}_{22} \mathrm{~N}_{4} \mathrm{O}_{2}^{+}\right), 275$ (17) $\left(\mathrm{C}_{14} \mathrm{H}_{19} \mathrm{~N}_{4} \mathrm{O}_{2}^{+}\right), 257$ (36) $\left(\mathrm{C}_{14} \mathrm{H}_{17} \mathrm{~N}_{4} \mathrm{O}^{+}\right), 245(74)\left(\mathrm{C}_{13} \mathrm{H}_{17} \mathrm{~N}_{4} \mathrm{O}^{+}\right), 232$ (100) $\left(\mathrm{C}_{12} \mathrm{H}_{18} \mathrm{~N}_{4} \mathrm{O}^{+}\right), 213$ (68), 199 (19), 187 (62), 174 (25), MS (ESI $\left.{ }^{+}\right) \mathrm{Da} / \mathrm{e}(\%): 291(100)(\mathrm{M}+\mathrm{H})^{+}$, $313(25)(\mathrm{M}+\mathrm{Na})^{+}$.

\section{2,7-Dihexylamino-4-methyl-[1.8]-naphthyridine 3e}

Yellow powder, mp $190^{\circ} \mathrm{C}$ (Found: C, 73.9; H, 9.8; N, 16.4 Calc. for $\mathrm{C}_{21} \mathrm{H}_{34} \mathrm{~N}_{4}$ (342.53). C, 73.6; $\mathrm{H}$, $10.0 ; \mathrm{N}, 16.4 ; \delta_{\mathrm{H}}\left(500 \mathrm{MHz}, \mathrm{CDCl}_{3}\right) 0.89(6 \mathrm{H}, \mathrm{t}, \mathrm{J} 6.31,2 \mathrm{x} \mathrm{H} \zeta), 1.34$ and $1.42(12 \mathrm{H}, \mathrm{m}, \mathrm{J}$ 6.31, 2x

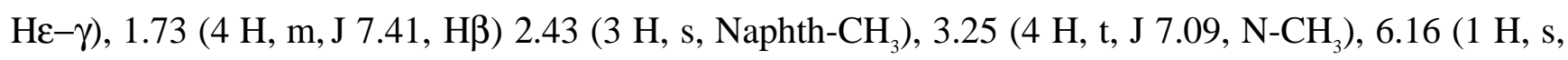
H3), 6.32 (1 H, d, J 8.83, H6), $7.70(1 \mathrm{H}, \mathrm{d}, \mathrm{J} 8.83, \mathrm{H} 5) ; \delta_{\mathrm{C}}\left(125 \mathrm{MHz}, \mathrm{CDCl}_{3}\right) 14.0\left(\mathrm{CH}_{3}-\zeta\right), 18.6$ (Naphth- $\left.\mathrm{CH}_{3}\right), 22.6\left(\mathrm{CH}_{2}-\varepsilon\right), 26.8\left(\mathrm{CH}_{2}-\gamma\right), 29.0\left(\mathrm{CH}_{3}-\beta\right), 31.6\left(\mathrm{CH}_{3}-\delta\right), 42.7\left(\mathrm{~N}_{-} \mathrm{CH}_{2}\right), 110.6(\mathrm{C} 3)$,

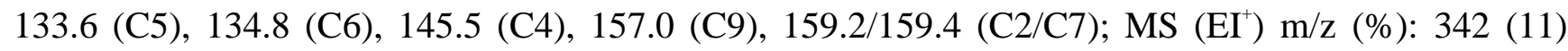
$\left(\mathrm{C}_{21} \mathrm{H}_{34} \mathrm{~N}_{4}^{+}\right), 313(6)\left(\mathrm{C}_{19} \mathrm{H}_{29} \mathrm{~N}_{4}^{+}\right), 285$ (15) $\left(\mathrm{C}_{17} \mathrm{H}_{25} \mathrm{~N}_{4}^{+}\right), 271$ (15), 259 (89), 243 (11), 230 (15), 202 (62) $\left(\mathrm{C}_{11} \mathrm{H}_{14} \mathrm{~N}_{4}^{+}\right), 188(100)\left(\mathrm{C}_{10} \mathrm{H}_{12} \mathrm{~N}_{4}^{+}\right), 175$ (83), $159(34)\left(\mathrm{C}_{9} \mathrm{H}_{9} \mathrm{~N}_{3}^{+}\right)$.

Acknowledgement: We gratefully acknowledge the support by Prof. Dr. R. Beckert Inst. of Organic Chemistry Jena and Prof. Dr. Stelzner of Institute of Virology Jena. 


\section{References and Notes}

1. a) Kricka, L.J. Nonisotopic DNA Probe Techniques, Acedemic Press, New York 1992; b) R. H. Symons, Nucleic Acid Probes, CRC Press 1989; c) Connolly, B.A.; Newman, P.C. Nucleic Acids Res. 1989, 17, 4957 - 4971.

2. Drexhage, K.H.; Erikson, G.R.; Hawks, G.H.; Reynolds, G.A. Opt. Commun., 1975, 15, 399-403;

b) Drexhage, K.H.; Reynolds, G.A. Opt. Commun. 1973, 13, 222-225; c) Drexhage, K.H. USP 3 873 940/1971.

3. Fletcher, A.N. Appl. Phys. 1977, 14, 295-302.

4. Hammond, P.R.; Atkins, R.L.; Henry, R.A.; Fletcher, A.N. USP 4 103 257/1976.

5. Staubli, A.B.; Dervan, P.B. Nucleic Acids Res. 1994, 22, 2637- 2642.

6. Meier, T. Ph.D. Thesis, University of Konstanz Germany, 1995.

7. Seide, O. Chem. Ber. 1926, 59, 2465-2473.

8. Petrow, V.; Rewald, E.L.; Sturgeon, B. J. Chem. Soc. 1947, 1407-1411.

9. Mangini, A.; Colonna, M. Gazz. Chim. Ital. 1942, 72, 190-195.

10. a) Bergstrom, F.W. J. Org. Chem. 1946, 11, 239-246; b) Wozniak, M.; Skiba, M. Pol. J. Chem. 1981, 55, 2429-2437.

11. Ochiai, E.; Miyaki, K. Chem. Ber. 1941, 74, 1115-1126; ref. 9.

12. Carboni, S.; Settimo, A.; Bertini, D.; Ferrarini, P.; Livi, O.; Tonetti, I. Il Farmaco 1975, 30, 185 196.

13. Hammond, P.R.; Fletcher, A.N.; Henry, R.A.; Atkins, R.L. Appl. Phys. 1975, 8, 315-318.

14. Obtained from Aldrich.

15. Haugland, J. Handbook of Fluorescent Probes, Mol. Ed. Probes Inc., Junction City, Oregon 1986.

16. Methods used for our experiments refer to J.S. Ploem, Fluorescence microscopy in Light Microscopy - A Practical Approach, ed. A.J. Lacey, IRL Press, Oxford, 1989, p. 137 and references cited herein.

17. Schmidtke, M.; Reichert, J.; Hoock, C. Unpublished work.

18. Schmidtke, M.; Knorre, C.; Blei, L.; Stelzner, A.; Birch-Hirschfeld, E. Nucleosides, Nucleotides 1998, 17, 1557-1566.

Samples Availability: Samples available from the authors.

(C) 1999 by the authors. Reproduction of this article, by any means, is permitted for noncommercial purposes. 